Vol. 4, No. 2, Desermber 2020, hal. 76-86

ISSN 2598-3245 (Print), ISSN 2598-3288 (Online)

DOI: http://doi.org/10.31961/eltikom.v4i2.150

Tersedia online di http://eltikom.poliban.ac.id

\title{
PENERAPAN METODE SIMPLE ADDITIVE WEIGHTING PADA SISTEM PENDUKUNG KEPUTUSAN PENERIMAAN PETUGAS DI BADAN PUSAT STATISTIK KABUPATEN BEKASI
}

\author{
Riko Reky Londong, Agung Nugroho, Adi Rusdi \\ Program Studi Teknik Informatika, Fakultas Teknik, Universitas Pelita Bangsa, Bekasi, Indonesia \\ e-mail: riko.londong@mhs.pelitabangsa.ac.id, \{agung, adirusdiw\}@ pelitabangsa.ac.id
}

Diterima: 20 Desember 2019 - Direvisi: 20 Juni 2020 - Disetujui: 2 Juli 2020

\begin{abstract}
Human resources planning is critical for a company, especially in terms of planning recruitment crite-ria that must be carried out appropriately to support the achievement of company objectives. Currently, the selection process for recruitment of officers at Badan Pusat Statistik Kabupaten Bekasi is still based on specific estimates and without definite variable values, so that it is often found that officers who are recruited do not have the criteria or abilities with the work required. To overcome these problems, a Deci-sion Support System needs to be made that can assist in determining the appropriate candidate in Badan Pusat Statistik Kabupaten Bekasi. The decision support system will be built using the Simple Additive Weighting method. The Development of the order using the Prototyping model system development meth-od, the system design uses Unified Modeling Language, testing using the BlackBox testing method and for implementing the system using web programming language, PHP, Javascript, and MySQL database. The results of this study are a decision support system for prospective acceptance officers using the SAW method. The conclusion is the Decision Support System using the SAW method has been successfully ap-plied and found the best alternative results for the recruitment of prospective officers, namely A4 alterna-tive, which has the highest value of 0.98 and alternative A3, A10 with a value of 0.92 .
\end{abstract}

Keywords: BPS, Decision Support System, Prototyping, Simple Additive Weighting (SAW).

\section{ABSTRAK}

Pentingnya perencanaan sumber daya manusia khususnya dalam hal perencanaan kriteria perekrutan harus dilakukan secara tepat guna mendukung tercapainya tujuan perusahaan. Saat ini, proses seleksi penerimaan petugas pada Badan Pusat Statistik Kabupaten Bekasi masih dilakukan berdasarkan perkiraan tertentu dan tanpa ada nilai variabel yang pasti, sehingga sering kali didapati petugas yang diterima kurang memiliki kriteria maupun kemampuan dengan pekerjaan yang dibutuhkan. Untuk mengatasi permasalahan tersebut pada penelitian ini bertujuan untuk membangun suatu Sistem Pendukung Keputusan yang dapat membantu dalam menentukan calon petugas yang sesuai di Badan Pusat Statistik Kabupaten Bekasi. Sistem Pendukung Keputusan yang dibangun menggunakan metode Simple Additive Weighting. Untuk pengembangan sistem yang digunakan adalah model Prototyping, desain sistem menggunakan Unified Modelling Language, pengujiannya menggunakan BlackBox Testing dan untuk implementasi sistem menggunakan bahasa pemograman web, PHP, Javascript dan database MySQL. Hasil dari penelitian ini adalah sebuah sistem pendukung keputusan penerimaan calon petugas menggunakan metode SAW. Kesimpulanya Sistem Pendukung Keputusan Peneriman Petugas dengan metode SAW telah berhasil diterapkan dan didapati hasil alternatif terbaik untuk penerimaan calon petugas yaitu alternatif A4 yang memiliki nilai tertinggi 0.98 dan alternatif A3, A10 dengan nilai 0.92.

Kata Kunci: BPS, Metode SAW, Prototyping, Sistem Pendukung Keputusan.

\section{PENDAhULUAN}

$\mathrm{D}$ I dalam sebuah instansi atau perusahaan, sumber daya manusia merupakan salah satu bagian yang penting agar perusahaan dapat berjalan dengan baik, sumber daya manusia yang baik akan mempengaruhi terhadap efektivitas perusahaan, dimana perusahaan akan lebih mudah untuk 


\section{Jurnal ELTIKOM : Jurnal Teknik Elektro, Teknologi Informasi dan Komputer}

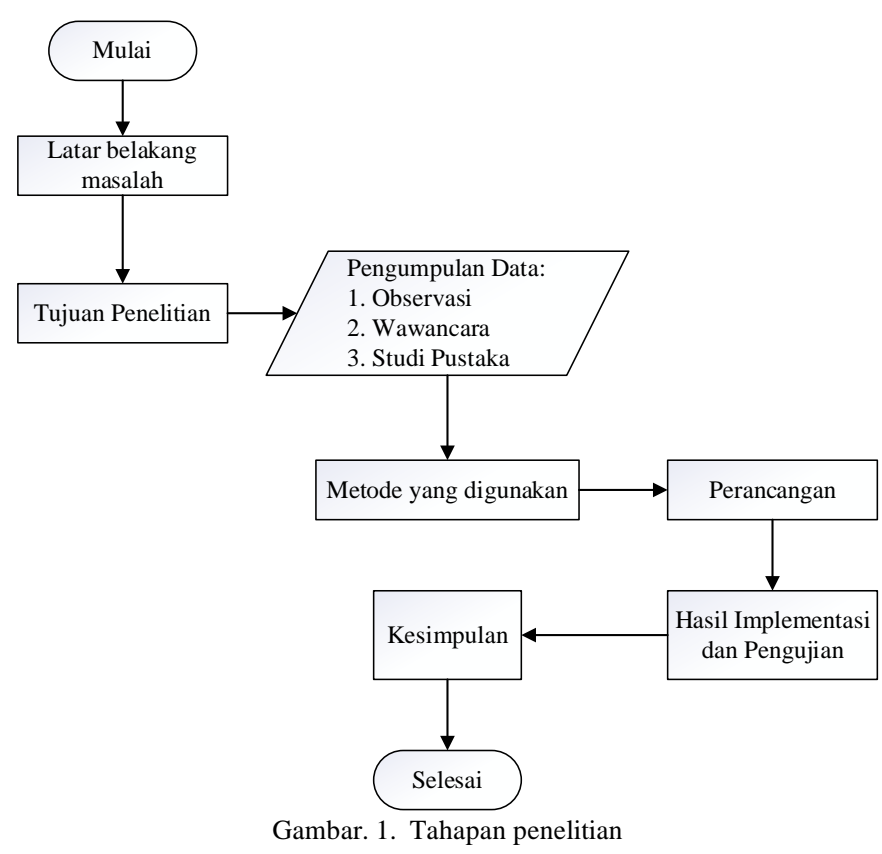

mencapai visi dan misi yang sudah terbentuk di awal berdirinya perusahaan [1].

Badan Pusat Statistik adalah lembaga pemerintah yang berperan menyediakan kebutuhan data statistik bagi pemerintah dan masyarakat, dalam memberikan hasil data yang valid, tentunya hal ini harus didampingi dengan kinerja para petugas yang baik dan optimal. Disamping itu peran divisi SDM dalam menangani permasalahan perekrutan petugas baru masih belum maksimal, karena saat ini proses seleksi penerimaan petugas yang berjalan pada Badan Pusat Statistik Kabupaten Bekasi hanya berdasarkan perkiraan tertentu dan tanpa ada nilai variabel yang pasti, sehingga sering kali didapati kesalahan rekrutmen yang ternyata petugas tersebut kurang memiliki kriteria maupun kemampuan yang dibutuhkan untuk pekerjaan nya. Untuk mengatasi permasalahan tersebut perlu dibuat suatu Sistem Pendukung Keputusan yang dapat membantu dalam menentukan calon petugas yang sesuai di Badan Pusat Statistik Kabupaten Bekasi.

Sistem Pendukung Keputusan atau biasa disingkat SPK merupakan bagian dari sistem informasi yang berbasis komputer. Sistem ini dibuat untuk membantu manajemen dalam pengambilan keputusan untuk hal ini terkait penerimaan calon petugas baru. Sistem Pendukung Keputusan dapat memberikan sebuah alternatif solusi kepada manajemen apabila manajemen kesulitan dalam pengambilan sebuah keputusan [2]. Terdapat beberapa metode pengambil keputusan salah satu nya adalah Simple Additive Weighting (SAW).

Pada penerapan metode SAW perhitungan nilai dari setiap kriteria yang diujikan akan memiliki skala prioritas bobot yang berbeda. Perhitungan dengan metode ini akan menghasilkan nilai yang beragam (non-identical) dan lebih spesifik sehingga manajer SDM maupun pimpinan mempunyai rekomendasi yang lebih akurat dalam menentukan pelamar-pelamar yang memiliki nilai terbaik sesuai dengan kebutuhan [3].

Berdasarkan pada penjelasan diatas maka penulis akan menerapkan metode keputusan model SAW untuk penerimaan calon petugas, Metode SAW ini dipilih karena diharapkan dapat memberikan penilaian yang akurat dan bertujuan untuk dapat menyeleksi calon petugas yang sesuai dengan yang dibutuhkan dan layak menjadi mitra statistik di Badan Pusat Statistik Kabupaten Bekasi.

\section{Metode Penelitian}

\section{A. Tahapan Penelitian}

Dalam penelitian ini untuk menerapkan Sistem Pendukung Keputusan penerimaan petugas pada Badan Pusat Statistik Kabupaten Bekasi dengan metode SAW, terdapat beberapa tahapan yang dilakukan yaitu seperti pada Gambar 1 . 


\section{Jurnal ELTIKOM : Jurnal Teknik Elektro, Teknologi Informasi dan Komputer}

\begin{tabular}{ccccccc}
\multicolumn{7}{c}{ TABEL 1 } \\
\hline DATA AlteRNATIF PETUGAS \\
Alternatif $\left(\mathrm{C}_{\mathrm{i}}\right)$ & Usia & $\begin{array}{c}\text { Pendidikan } \\
\text { Terakhir }\end{array}$ & Pengalaman & Motivasi & Wawancara & Kemampuan \\
\hline A1 & 35 & SMA & 1 & B & B & 70 \\
A2 & 46 & SD & 4 & C & C & 60 \\
A3 & 22 & SMA & 0 & A & A & 80 \\
A4 & 29 & D3 & 2 & A & A & 90 \\
A5 & 37 & SMP & 0 & C & B & 70 \\
A6 & 43 & SD & 3 & C & C & 60 \\
A7 & 23 & SMA & 0 & A & B & 50 \\
A8 & 32 & SMA & 1 & A & C & 60 \\
A9 & 34 & SD & 1 & B & A & 80 \\
A10 & 21 & SMA & 0 & A & A & \\
\hline \hline
\end{tabular}

Keterangan : $\mathrm{C}=$ Cukup B = Baik A = Amat Baik

\section{B. Metode Pengembangan Sistem}

Pada penelitian ini metode pengembangan sistem yang digunakan adalah System Development Life Cycle (SDLC), System Development Life Cycle (SDLC) adalah sebuah metode yang digunakan untuk mengembangkan sebuah sistem dan biasa digunakan oleh system analyst sebagai proses logika dalam mengembangkan sistem informasi dengan melibatkan requirements, validation, training dan pemilik sistem. Namun seiring perkembangan dunia teknologi dan pemikiran manusia, sistem yang digunakan pun akan semakin kompleks sedangkan waktu yang dibutuhkan untuk pengembangan sistem tersebut menjadi terbatas, kondisi ini menyebabkan metode SDLC belum cukup dalam memberikan solusi [4].

Sistem yang sedang berjalan atau sedang digunakan oleh organisasi maupun perusahaan akan terus dikembangan untuk memperbaiki kekurangan-kekurangan pada sistem tersebut dengan menggunakan suatu metode tertentu. Metode adalah tahap-tahap ataupun aturan untuk melakukan sesuatu, dalam melakukan pengembangan sistem metode yang digunakan adalah System Development Life Cycle [4].

Konsep SDLC mendasari model pengembangan perangkat lunak lainnya. Model pengembangan perangkat lunak tersebut antara lain prototyping, iterative, spiral, rapid application development (RAD) dan lainnya [5]. Dalam penelitian ini model pengembangan perangkat lunak yang digunakan adalah model prototyping.

Prototyping merupakan teknik pengembangan sistem yang menggunakan purwarupa untuk menggambarkan sistem sehingga pengguna atau pemilik sistem mempunyai gambaran pengembangan sistem yang akan dilakukan, teknik ini sering digunakan apabila pengguna belum terlalu menguasai teknologi dari sistem yang akan dikembangkanya tersebut [4].

\section{Metode SAW Untuk Penerimaan Calon Petugas}

Untuk melakukan seleksi penerimaan calon petugas, pada penilitian ini penulis menggunakan metode Simple Additive Weighting atau model logika fuzzy SAW. SAW merupakan suatu metode untuk penjumlahan secara terbobot, konsep dasar SAW adalah mencari penjumlahan terbobot dari rating kinerja pada setiap alternatif pada semua atribut [6]. Metode ini mengharuskan pembuat keputusan menentukan bobot bagi setiap atribut. Skor total untuk sebuah alternatif diperoleh dengan menjumlahkan seluruh hasil perkalian antara rating (yang dapat dibandingkan lintas atribut) dan bobot tiap atribut. Rating tiap atribut haruslah bebas dimensi yang artinya telah melewati proses normalisasi sebelumnya [3]. Berikut adalah tahap-tahap dalam menerapkan metode SAW [7].

\section{1) Menentukan alternatif (kandidat)}

Tahap pertama dalam memulai penghitungan dengan metode SAW adalah dengan menentukan alternatif atau kandidat terlebih dahulu, pada penelitian ini data alternatif yang digunakan adalah data yang ditetapkan berdasarkan hasil pengumpulan data calon petugas yang ada di Badan Pusat Statistik Kabupaten Bekasi seperti yang dapat dilihat pada Tabel 1.

\section{2) Menentukan kriteria dan pembobotan}

Selanjutnya untuk menyeleksi calon petugas yang diterima yaitu dengan menentukan kriteria dan memberikan nilai bobot untuk masing- masing kriteria dengan metode SAW. Berdasarkan hasil observasi dan wawancara yang telah dilakukan maka didapati beberapa kriteria yang dibutuhkan untuk 


\section{Jurnal ELTIKOM : Jurnal Teknik Elektro, Teknologi Informasi dan Komputer}

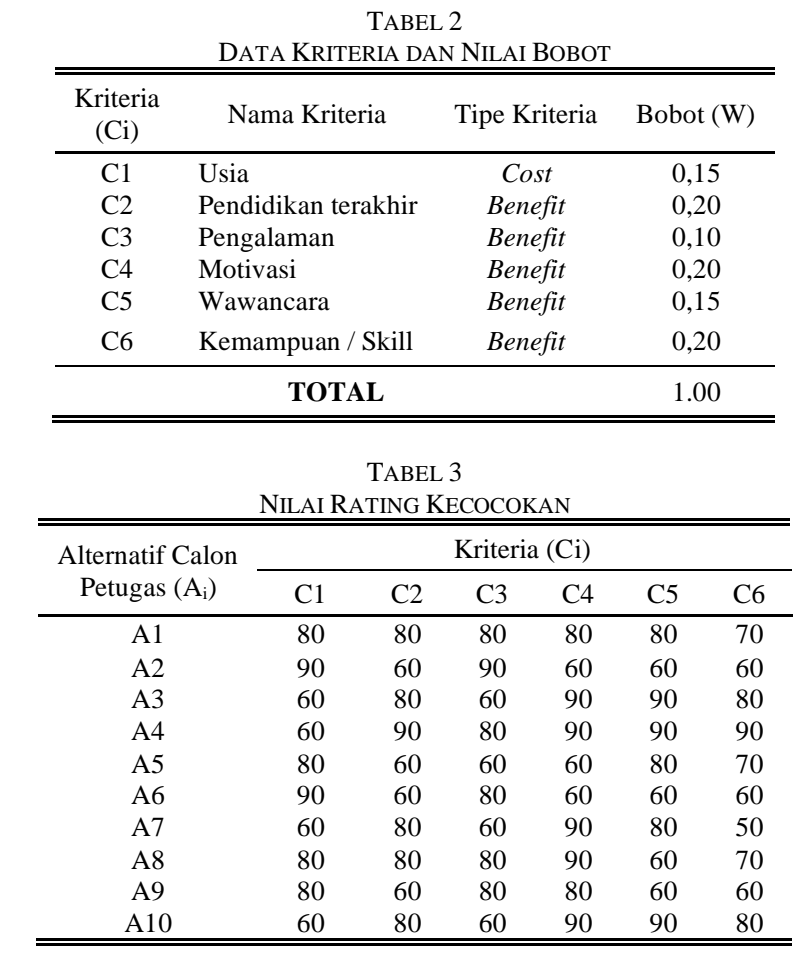

menjadi calon petugas, kriteria tersebut terdiri dari Usia, Pendidikan Terakhir, Pengalaman Kerja, Motivasi, Wawancara, dan Kemampuan / Skill, Sedangkan untuk penentuan nilai bobot diperoleh berdasarkan tingkat kepentingan dari masing-masing kriteria. Tabel 2 merupakan perincian kriteria yang digunakan dan nilai bobot dalam menyeleksi penerimaan petugas.

Dari 6 kriteria tersebut hanya kriteria usia saja yang menjadi tipe kriteria cost (semakin kecil semakin bagus), karena semakin besar usia dari pelamar maka semakin kecil kesempatan terpilih untuk menjadi calon petugas di BPS. Berikut adalah beberapa keterangan nilai dari setiap kriteria yang digunakan. Kriteria $\mathrm{C} 1$ adalah nilai dari usia yang menjadi persyaratan untuk menjadi calon petugas, jika usia (19 s/d 29) maka mendapatkan nilai 60, jika usia (30 s/d 39) maka mendapatkan nilai 80. dan jika memiliki nilai kriteria usia (40 s/d 45) maka akan mendapatkan nilai 90 . Kriteria $\mathrm{C} 2$ adalah nilai dari pendidikan terakhir yang telah ditempuh oleh calon petugas. Jika pendidikan terakhir yang ditempuhnya (SD s/d SMP) maka mendapatkan Nilai 60, jika pendidikan terakhirnya (SMA/Sederajat) maka akan mendapatkan Nilai 80, dan jika memiliki pendidikan terakhir (D3 s/d S1) maka akan mendapatkan Nilai 90. Kriteria $\mathrm{C} 3$ adalah nilai dari pengalaman yang dimiliki oleh calon petugas, jika belum memiliki pengalaman (pengalaman $=0$ ) maka mendapatkan nilai 60, jika mempunyai pengalaman bekerja kurang dari 3 maka mendapatkan nilai 80. dan jika memiliki banyak pengalaman pekerjaan (pengalaman > 3) maka akan mendapatkan nilai 90. Kriteria C4 dan C5 adalah penilaian yang diberikan sesuai dari hasil wawancara terhadap calon petugas, jika calon petugas memiliki motivasi dan hasil wawancara yang cukup maka mendapatkan nilai 60, jika memperoleh hasil yang baik mendapatkan nilai 80,dan 90 apabila hasilnya amat baik. Kriteria kemampuan (skill) adalah penilaian yang diberikan berdasarkan hasil dari tes yang telah dilakukan oleh calon petugas. Penilaian yang diberikan pada kriteria ini memiliki nilai yang beragam, tergantung dari perolehan nilai dari hasil tes. Nilai tertinggi yang dapat diperoleh pada kriteria ini adalah 100.

\section{3) Menentukan nilai rating kecocokan}

\section{4) Melakukan normalisasi matriks}

Berdasarkan nilai rating kecocokan yang telah disesuaikan seperti pada Tabel 3, maka tahapan selanjutnya adalah membuat matrik keputusan (X) yang dibentuk dari tabel rating kecocokan dari setiap alternatif pada setiap kriteria untuk melakukan normalisasi dengan cara menghitung nilai rating kinerja ternomalisasi (R). Berikut adalah matriks (X) keputusanya. 


\section{Jurnal ELTIKOM : Jurnal Teknik Elektro, Teknologi Informasi dan Komputer}

$$
x=\left[\begin{array}{llllll}
80 & 80 & 80 & 80 & 80 & 70 \\
90 & 60 & 90 & 60 & 60 & 60 \\
60 & 80 & 60 & 90 & 90 & 80 \\
60 & 90 & 80 & 90 & 90 & 90 \\
80 & 60 & 60 & 60 & 80 & 70 \\
90 & 60 & 80 & 60 & 60 & 60 \\
60 & 80 & 60 & 90 & 80 & 50 \\
80 & 80 & 80 & 90 & 60 & 70 \\
80 & 60 & 80 & 80 & 60 & 60 \\
60 & 80 & 60 & 90 & 90 & 80
\end{array}\right]
$$

Nilai skor yang di input pada matriks (X) diatas adalah nilai pada setiap kriteria C1, C2, C3, C4, C5, dan C6, dari skor yang sudah diinput selanjutnya dilalukan perhitungan normalisasi (R) dengan menggunakan rumus yang sesuai dengan jenis atribut kriteria penilaian, rumus normalisasi nya adalah sebagai berikut.

$$
r_{i j}=\left\{\begin{array}{l}
\frac{x_{i j}}{\max x_{i j}}, j i k a j \text { adalah atribut keuntungan (benefit) } \\
\frac{\min x_{i j}}{x_{i j}}, j i k a j \text { adalah atribut biaya }(\text { cost })
\end{array}\right.
$$

Keterangan

$\mathrm{r}_{\mathrm{ij}} \quad$ : nilai rating kinerja ternormalisasi,

$\mathrm{x}_{\mathrm{ij}} \quad$ : nilai atribut yang dimiliki dari setiap kriteria,

$\operatorname{Max} \mathrm{x}_{\mathrm{ij}}$ : nilai terbesar dari setiap kriteria,

Min $\mathrm{x}_{\mathrm{ij}}$ : nilai terkecil dari setiap kriteria,

Benefit : jika nilai terbesar adalah terbaik, dan

Cost : jika nilai terkecil adalah terbaik.

Setelah semua data nilai alternatif dari setiap kriteria dihitung, maka diperoleh hasil dari nilai rating kinerja ternomalisasi dan membentuk matrik ternormalisasi. Berikut adalah matriks dari nilai rating yang sudah ternormalisasi.

$$
R=\left[\begin{array}{cccccc}
0,75 & 0,89 & 0,89 & 0,89 & 0,89 & 0,78 \\
0,67 & 0,67 & 1 & 0,67 & 0,67 & 0,67 \\
1 & 0,89 & 0,67 & 1 & 1 & 0,67 \\
1 & 1 & 0,89 & 1 & 1 & 0,89 \\
0,75 & 0,67 & 0,67 & 0,67 & 0,88 & 1 \\
0,67 & 0,67 & 0,89 & 0,67 & 0,67 & 0,55 \\
1 & 0,89 & 0,67 & 1 & 0,89 & 0,67 \\
0,75 & 0,89 & 0,89 & 1 & 0,67 & 0,78 \\
0,75 & 0,67 & 0,89 & 0,89 & 0,67 & 0,67 \\
1 & 0,89 & 0,67 & 1 & 1 & 0,89
\end{array}\right]
$$

\section{5) Menghitung nilai preferensi dan Perangkingan}

Langkah berikutnya adalah menghitung nilai preferensi yang diperoleh dari penjumlahan untuk setiap perkalian elemen baris matrik ternormalisasi (R) dengan bobot preferensi (W) yang bersesuaian dengan elemen kolom matrik. Dalam penelitian ini nilai bobot yang digunakan oleh pengambil keputusan adalah $\mathrm{W}=[0.10 ; 0.20 ; 0.10 ; 0.20 ; 0.15 ; 0.20]$. Dari hasil perhitungan nilai preferensi diatas, maka dibuat Tabel 4. Berdasarkan hasil perhitungan dan perangkingan pada Tabel 4, maka dapat diambil keputuskan bahwa yang menjadi kandidat atau alternatif terbaik untuk penerimaan calon petugas adalah A3, A10 dengan nilai 0.92 dan A4 yang memiliki nilai tertinggi yaitu 0.98 . 


\section{Jurnal ELTIKOM : Jurnal Teknik Elektro, Teknologi Informasi dan Komputer}

TABEL 4

HASIL PERANGKINGAN

\begin{tabular}{|c|c|c|}
\hline $\begin{array}{l}\text { Alternatif (Ai) } \\
\text { Calon Petugas }\end{array}$ & Hasil & Perangkingan \\
\hline $\mathrm{A} 4$ & 0.98 & 1 \\
\hline A3 & 0.92 & 2 \\
\hline A10 & 0.92 & 3 \\
\hline A1 & 0.84 & 4 \\
\hline A7 & 0.83 & 5 \\
\hline A 8 & 0.83 & 6 \\
\hline A9 & 0.74 & 7 \\
\hline A5 & 0.73 & 8 \\
\hline A 2 & 0.70 & 9 \\
\hline A6 & 0.68 & 10 \\
\hline
\end{tabular}

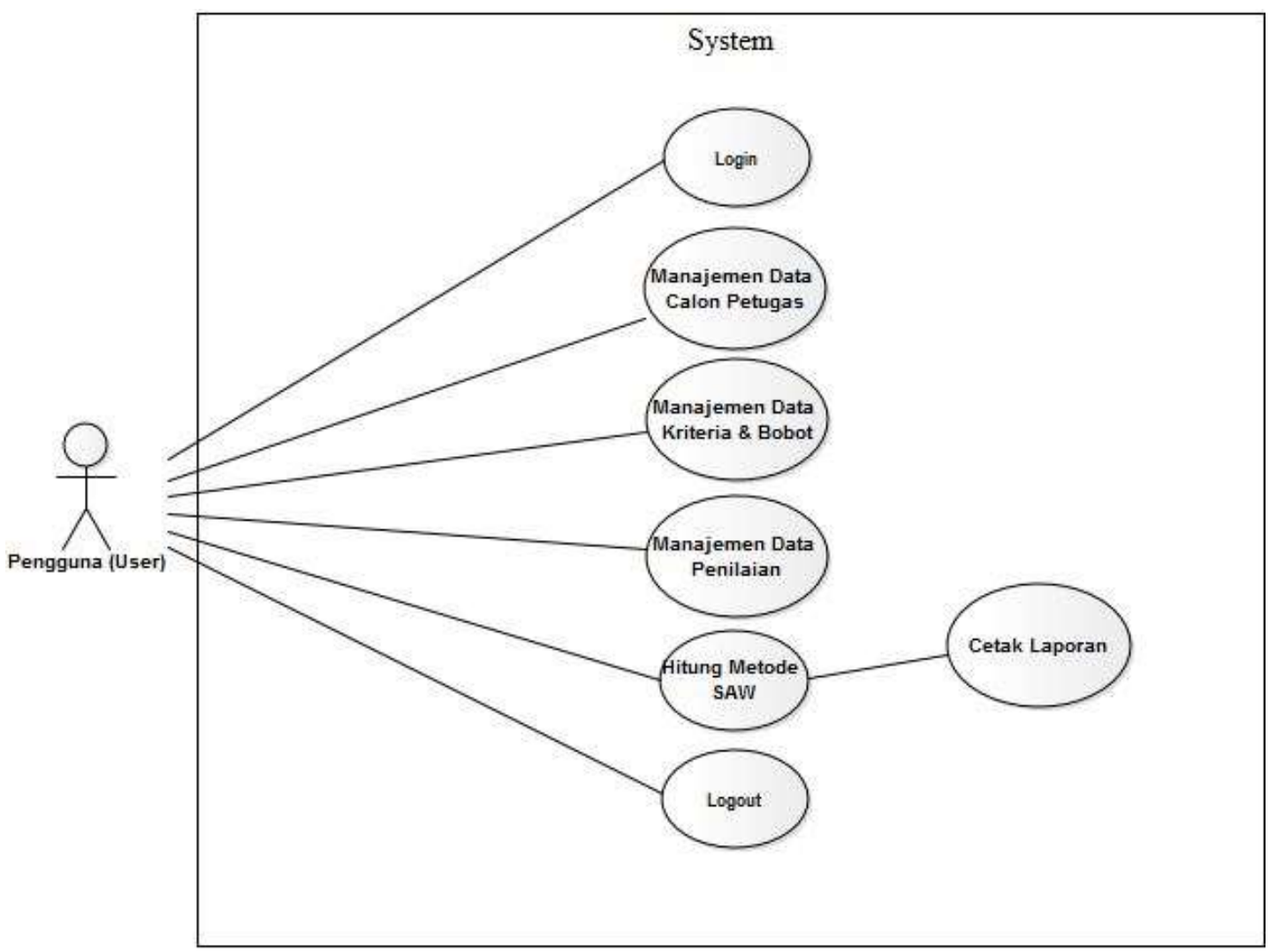

Gambar. 2. Use Case Diagram Sistem Pendukung Keputusan.

\section{Perancangan Sistem}

Perancangan dalam membangun sistem pendukung keputusan ini terdiri dari perancangan sistem dengan menggunakan pemodelan UML. Unified modeling language (UML) adalah bahasa pemodelan untuk sistem atau perangkat lunak, dengan UML, dapat dibuat model bagi semua jenis aplikasi yang dapat berjalan pada piranti keras, sistem operasi dan jaringan, serta ditulis dalam bahasa pemrograman apapun [6]. Bahasa Pemodelan UML lebih cocok untuk pembuatan perangkat lunak dalam bahasa pemrograman berorientasi objek, namun demikian tetap dapat digunakan pada bahasa pemrograman prosedural [8].

Use case diagram merupakan pemodelan untuk kelakuan (behavior) sistem informasi yang akan dibuat [9]. Berikut ini merupakan use case diagram pada sistem pendukung keputusan penerimaan petugas di Badan Pusat Statistik Kabupaten Bekasi berdasarkan algoritma SAW. Use case diagram menggambarkan fungsionalitas sistem yang merepresentasikan interaksi antara pengguna (aktor) yang bertujuan untuk menentukan bagaimana aktor berinteraksi dengan sebuah sistem [10]. Berdasarkan diagram use case pada Gambar 2, terdapat beberapa kebutuhan fungsional sistem. Berikut adalah kebutuhan fungsional sistem yang dimiliki.

- Pengguna (User) dapat melakukan login. 


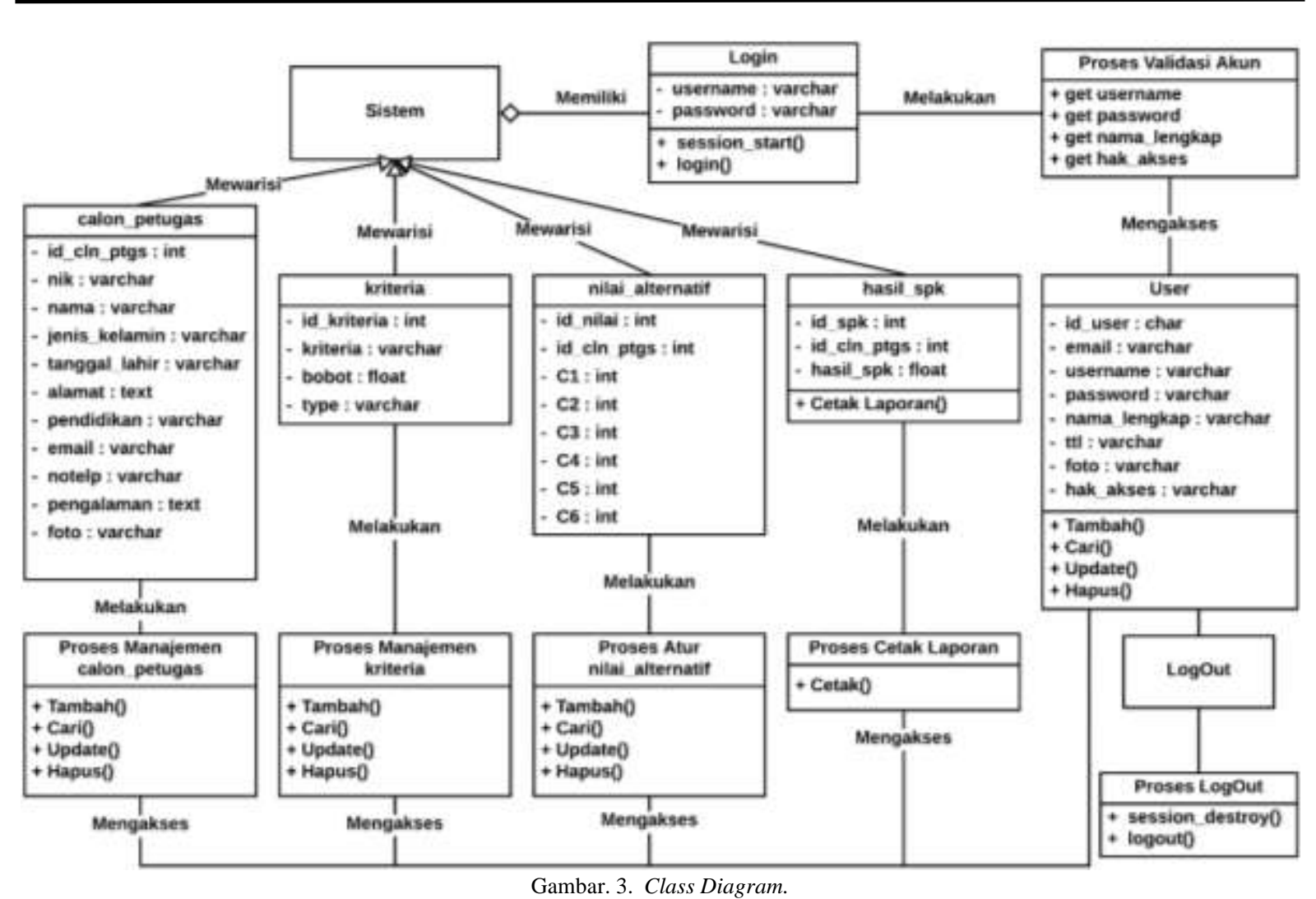

- $\quad$ Pengguna (User) dapat mengelola data calon petugas.

- Pengguna (User) dapat mengelola data kriteria dan bobot.

- Pengguna (User) dapat mengelola data penilaian.

- Pengguna (User) dapat melakukan proses hitung dengan metode SAW.

- Pengguna (User) dapat melihat dan mencetak laporan.

- Pengguna (User) dapat melakukan logout.

Class diagram menggambarkan struktur statis dari kelas dalam sistem dan menggambarkan atribut, operasi dan hubungan antara kelas. Class diagram juga menunjukkan atribut-atribut dan operasi-operasi dari sebuah kelas dan constraint yang berhubungan dengan objek yang dikoneksikan [9]. Class diagram membantu dalam memvisualisasikan struktur kelas-kelas dari suatu sistem. Selama tahap desain, class diagram berperan dalam menangkap struktur dari semua kelas yang membentuk arsitektur sistem yang dibuat. Adapun bentuk class diagram yang penulis rancang dapat dilihat pada Gambar 3.

\section{E. Basis Data}

Pada penelitian ini MySQL digunakan sebagai media penyimpanan dan pengelolaan basis data. MySQL merupakan program pembuat dan pengelola database atau sering disebut dengan DBMS (Database Management System), MySQL adalah sistem manajemen database SQLyang bersifat open source dan paling populer saat ini. Database ini dibuat untuk keperluan sistem database yang cepat handal dan mudah digunakan [11].

\section{F. Desain Tampilan Antarmuka Sistem}

User interface (UI) atau tampilan antarmuka pengguna merupakan bagian yang penting dalam sebuah sistem atau aplikasi. UI adalah bagian dari sistem yang digunakan untuk berinteraksi langsung dari pengguna [12]. Pada desain antarmuka sistem pendukung keputusan ini terdiri dari beberapa menu seperti Menu login digunakan untuk pengguna masuk dalam halaman menu utama dan menampilkan dashboard. Bentuk perancangan pada menu ini dapat dilihat pada Gambar 4 dan Gambar 5.

Selanjutnya desain tampilan halaman menu proses hitung dengan metode SAW merupakan tampilan untuk mengolah data penilaian calon petugas pada setiap nilai kriteria dan melakukan proses perhitungan yang digunakan untuk proses perangkingan. Bentuk perancangan pada menu hitung dengan metode SAW dapat dilihat pada Gambar 6. Lalu pada Gambar 7 merupakan perancangan halaman laporan penerimaan calon petugas, halaman ini merupakan tampilan untuk hasil cetak laporan data penerimaan calon petugas. 


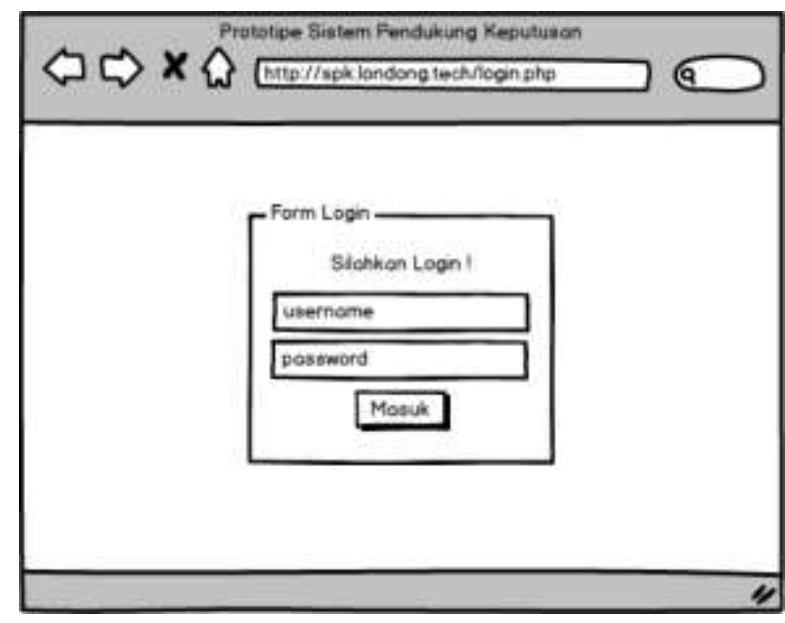

Gambar. 4. Desain Halaman Menu Login.

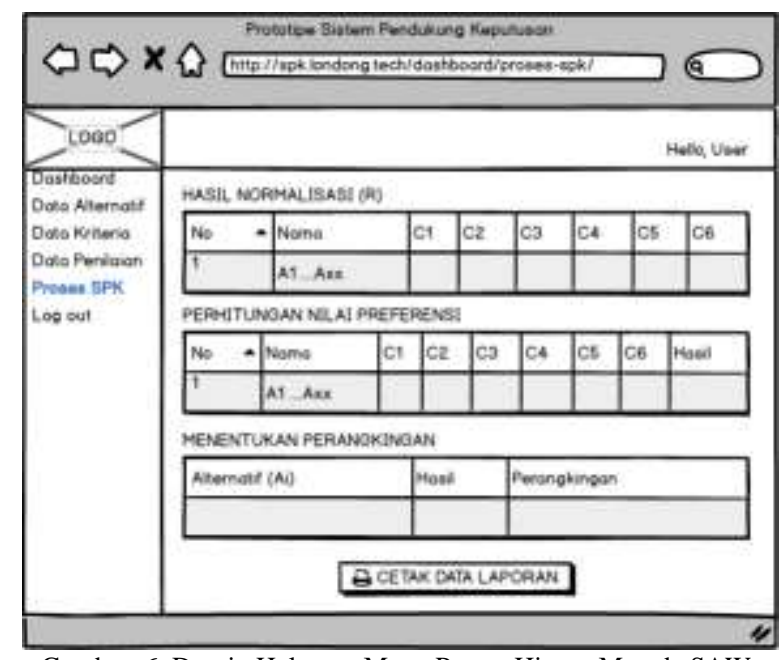

Gambar. 6. Desain Halaman Menu Proses Hitung Metode SAW.

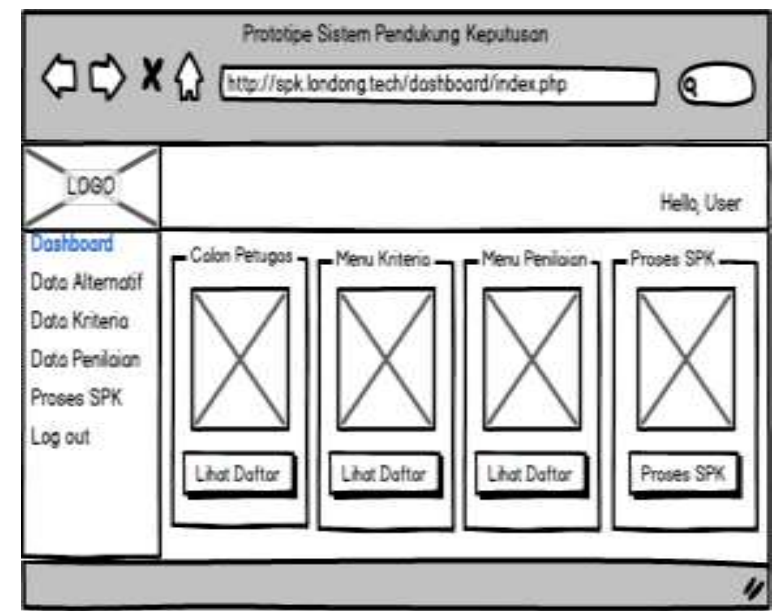

Gambar. 5. Desain Halaman Menu Utama (Dashboard).

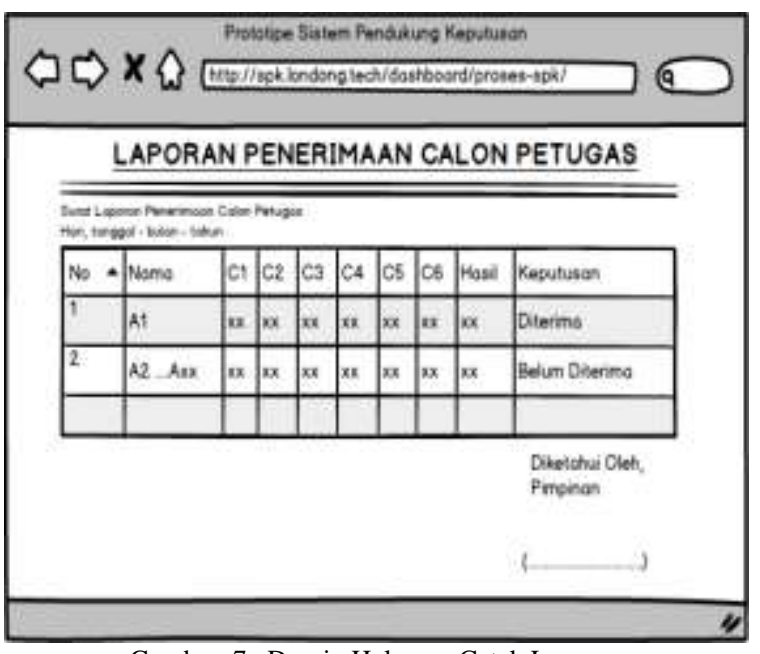

Gambar. 7. Desain Halaman Cetak Laporan.

\section{HASIL DAN PEMBAHASAN}

\section{A. Sistem yang dibangun}

Implementasi sistem merupakan hasil penerapan kedalam sistem dari perancangan sesuai dengan desain Input dan Output yang telah dibahas sebelumnya. Berikut dibawah ini adalah hasil implementasi sistem yang diperoleh dari tampilan antarmuka sistem pendukung keputusan penerimaan petugas dengan metode SAW.

Halaman menu login digunakan untuk pengguna melakukan login untuk mengakses menu utama, pengguna harus memasukkan nama penggguna (Username) dan Password untuk masuk kedalam halaman menu utama dan menampilkan Dashboard. Hal ini dapat dilihat pada Gambar 8.

\section{B. Hasil pengujian}

Pada aplikasi sistem pendukung keputusan penerimaan petugas di Badan Pusat Statistik Kabupaten Bekasi dengan metode SAW. Pengujian dilakukan dengan menggunakan Black Box Testing kemudian membandingkan hasil keluaran dengan hasil yang diharapkanan., Pengujian yang dilakukan merujuk pada fungsi-fungsi yang dimiliki sistem mulai dari Halaman Login, Dashboard, Halaman Proses Metode SAW, dan Cetak Laporan. Hasil pengujian yang telah dilakukan pada sistem pendukung keputusan penerimaan petugas menunjukkan semua kebutuhan fungsi-fungsi sistem telah berjalan dengan baik dan sesuai dengan yang diharapkan.

\section{Pembahasan}

Sumber daya manusia yang kompeten merupakan salah satu faktor untuk memperoleh keberhasilan dalam mengatasi persaingan industri perusahaan yang tinggi. Pentingnya perencanaan sumber daya 


\section{Jurnal ELTIKOM : Jurnal Teknik Elektro, Teknologi Informasi dan Komputer}

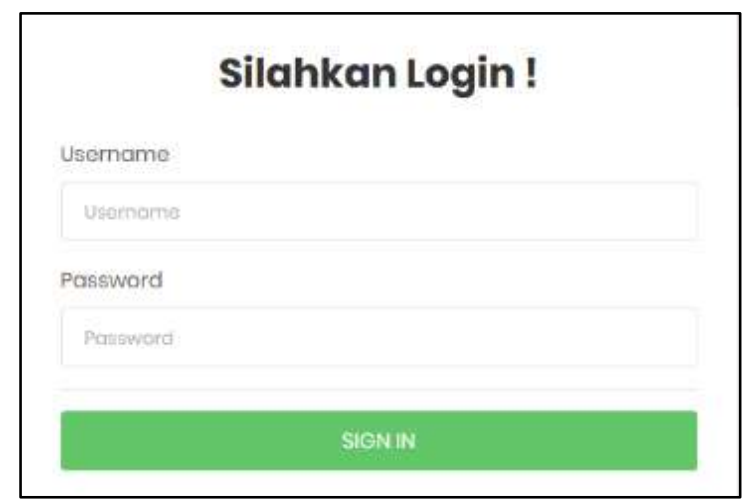

Gambar. 8. Tampilan Halaman Menu Login

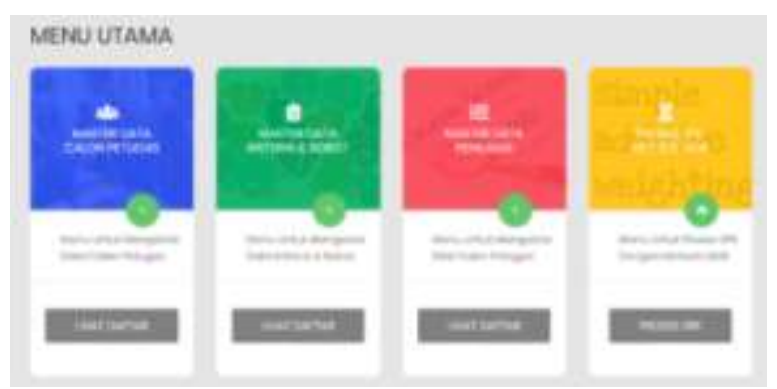

Gambar. 9. Tampilan Halaman Menu Utama (Dashboard)

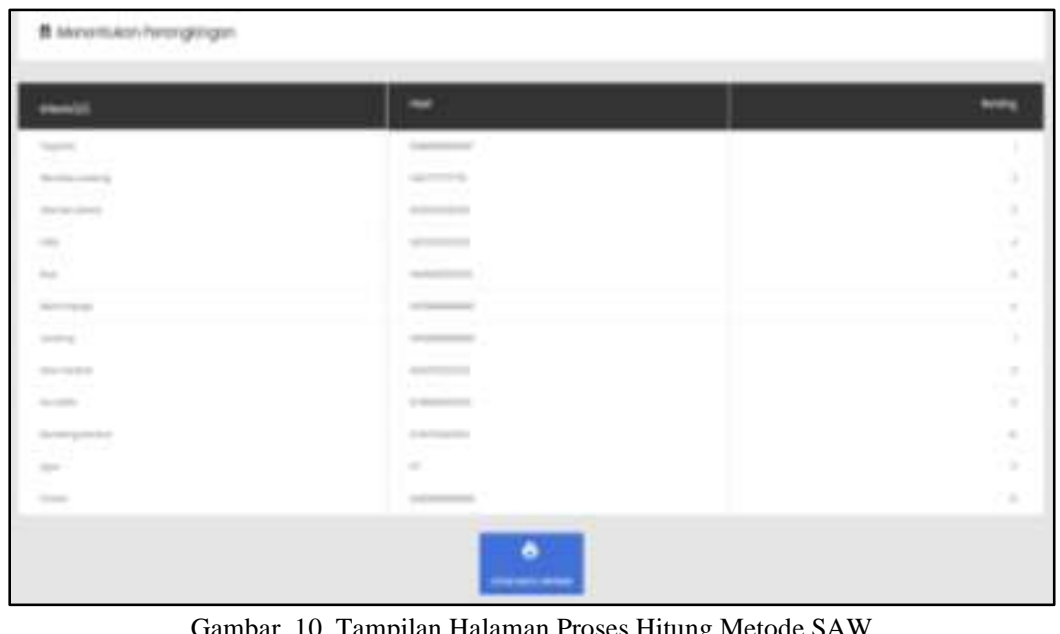

Gambar. 10. Tampilan Halaman Proses Hitung Metode SAW

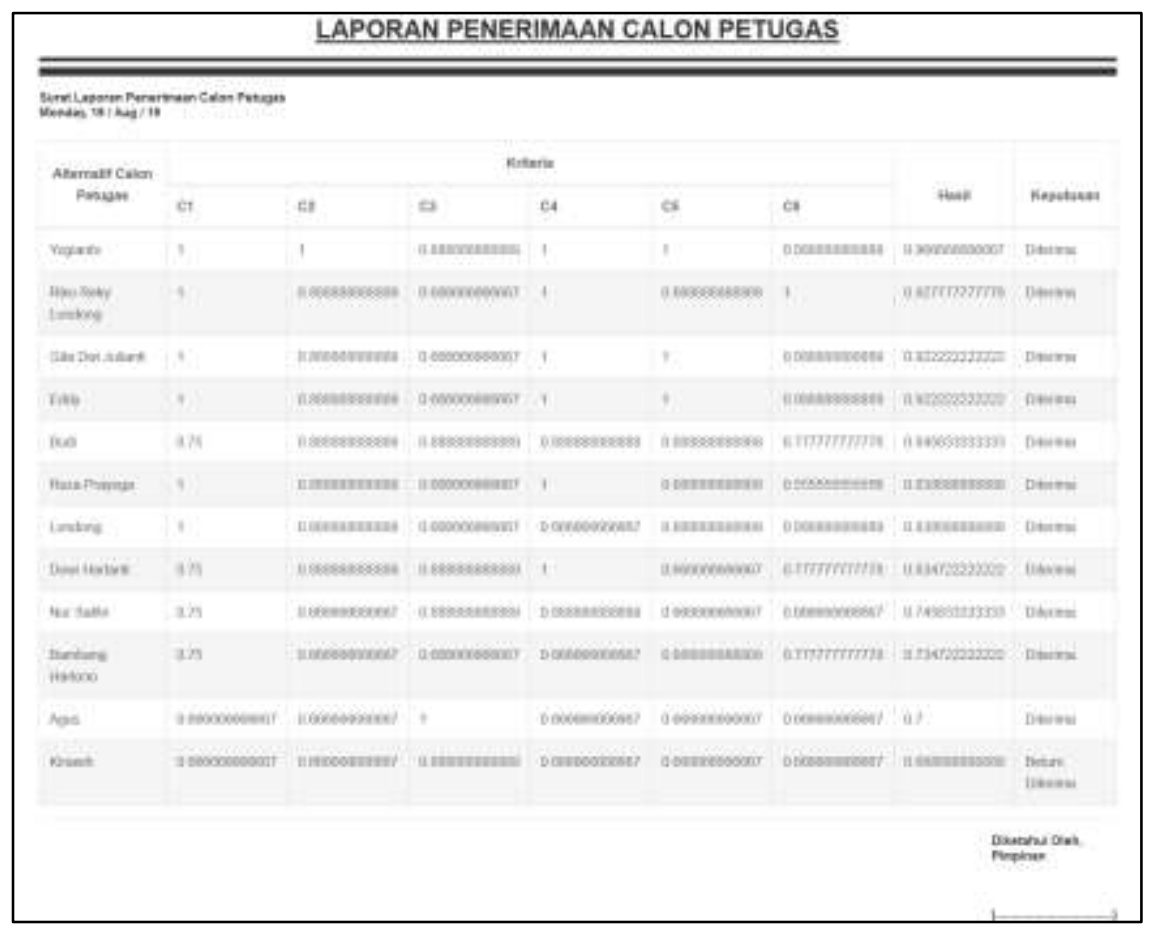

Gambar. 11. Tampilan Halaman Cetak Laporan

manusia khususnya dalam hal perencanaan kriteria perekrutan sumber daya manusia harus dilakukan secara tepat dan disesuaikan dengan permintaan masing-masing bagian guna mendukung tercapainya tujuan perusahaan [13]. Oleh karena itu dalam meningkatkan kinerja sumber daya manusia di dalam 


\section{Jurnal ELTIKOM : Jurnal Teknik Elektro, Teknologi Informasi dan Komputer}

lingkungan pekerjaan, manajemen sumber daya manusia perlu lebih dikembangkan. Dalam mengatasi permasalahan kriteria untuk perekrutan tersebut perlu dibuat suatu sistem pendukung keputusan yang pada penelitian ini yaitu untuk dapat membantu dalam menentukan calon petugas yang sesuai di Badan Pusat Statistik Kabupaten Bekasi.

Terdapat beberapa metode pengambil keputusan seperti pada penelitian sebelumnya oleh Muqorobin dkk yang membahas tentang sistem pendukung keputusan untuk menentukan penerimaan beasiswa menggunakan metode Simple Additive Weighting. Dari hasil pengujian sistem, penerapan metode SAW dapat menghasilkan perangkingan sebagai rujukan terbaik bagi calon penerima beasiswa dan dapat berjalan dengan baik sesuai dengan hasil scenario uji pada pengujian fungionalitas menghasilkan output yang diharapkan [14]. Selain itu ada pula penelitian yang dilakukan oleh Taufiq dkk yang menerapkan metode SAW, dari penelitian ini telah dihasilkan sistem pendukung keputusan metode SAW yang dapat membandingkan penilaian yang akurat sehingga mendapatkan calon karyawan yang sesuai dengan perusahaan butuhkan [15].

Berdasarkan dari beberapa penelitian terdahulu tersebut memiliki keterkaitan dengan penelitian yang dilakukan penulis yaitu membahas sistem pendukung keputusan dengan metode Simple additive Weighting, selain itu dapat diketahui juga bahwa sistem pendukung keputusan dengan metode SAW mampu menyelesaikan suatu masalah dengan menggunakan kriteria tertentu sesuai dengan tujuan keputusan yang diambil, maka dari itu penulis bertujuan untuk menerapkan metode SAW agar dapat menyelesaikan permasalahan dalam menyeleksi calon petugas di Badan Pusat Statistik Kabupaten Bekasi.

\section{KESIMPULAN}

Dalam penerapan metode Simple additive weighting (SAW) untuk menentukan penerimaan calon petugas pada penelitian ini menggunakan 6 kriteria yang terdiri dari Usia (C1), Pendidikan Terakhir (C2), Pengalaman (C3), Motivasi (C4), Wawancara (C5), dan Kemampuan atau Skill (C6). Berdasarkan hasil perhitungan menggunakan 10 data alternatif calon petugas, didapati hasil alternatif terbaik untuk penerimaan calon petugas yaitu alternatif A4 yang memiliki nilai tertinggi 0.98 dan alternatif A3, A10 dengan nilai 0.92. Dari perolehan hasil perhitungan menggunakan metode SAW tersebut selanjutnya diterapkan pada sistem pendukung keputusan yang dirancang sehingga perhitungan tersebut akan lebih cepat dan dapat membantu proses penerimaan calon petugas di Badan Pusat Statistik Kabupaten Bekasi agar terpilih petugas yang benar-benar layak.

Saran yang dapat digunakan untuk penelitian kedepanya yaitu untuk pengembangan sistem pendukung keputusan selanjutnya dapat dikembangkan dengan menggunakan metode lain atau penggabungan dari beberapa metode seperti Analitycal hierarchy process (AHP), Elimination and choise expressing reality (ELECTRE), TOPSIS, dan lainnya agar dapat memperoleh pengambilan keputusan dengan keakuratan yang lebih tepat lagi. Selain itu diperlukan juga untuk meningkatkan kualitas sistem dengan mempertimbangkan sisi keamanan dari sistem untuk mencegah pencurian data data yang penting.

\section{DAFTAR PUSTAKA}

[1] R. Nugroho, B. S. Sunuharjo, and I. Ruhana, "Pengaruh Iklim Organisasi BPS dan Stres Kerja Terhadap Kinerja Karyawan ( Studi pada karyawan Badan Pusat Statistik ( BPS ) Kabupaten Kediri )," J. Adm. Bisnis, vol. 45, no. 1, 2017.

[2] R. P. A. Nugroho and Purwanto, "Rancangan Sistem Pendukung Keputusan Penerimaan Pegawai Menggunakan Metode Profil Matching," Eksplora Inform., vol. 5, no. 1, pp. 33-42, 2015.

[3] A. Rahadi, "Perbandingan Metode Analytical Hirearchy Process Dengan Metode Simple Additive Weighting Untuk Perekrutan Dosen Pada IBI Darmajaya Lampung," J. Sist. Inf. dan Telemat., vol. 8, no. 1, 2017.

[4] S. Mulyani, Metode Analisis dan Perancangan Sistem, ISBN: 978-979-19906-2-2, vol. Edisi Ke-2. Bandung: Abdi Sistematika, 2016.

[5] R. Susanto and A. D. Andriana, "Perbandingan Model Waterfall Dan Prototyping Untuk Pengembangan Sistem Informasi," Maj. Ilm. UNIKOM, vol. 14, no. 1, pp. 41-46, 2016.

[6] S. Aisyah, “Aplikasi Sistem Pendukung Keputusan Analisis Kelayakan Pada Perusahaan Leasing,” J. Teknovasi, vol. 06, pp. 1-16, 2019.

[7] Diana, Metode Dan Aplikasi Sistem Pendukung Keputusan. Yogyakarta: Deepublish (CV Budi Utama), 2018.

[8] O. Fajarianto, "Prototype Pelayanan Akademik Terhadap Komplain Mahasiswa Berbasis Mobile," J. Lentera Ict, vol. 3, no. 1, pp. 54$60,2016$.

[9] A. Hendini, "Pemodelan UML Sistem Informasi Monitoring Penjualan dan Stok Barang (Studi Kasus: Distro Zhezha Pontianak)," J. KHATULISTIWA Inform., vol. VOL. IV, no. NO. 2, pp. 107-116, 2016.

[10] A. P. Windarto, "Penilaian Prestasi Kerja Karyawan PTPN III Pematangsiantar Dengan Metode Simple Additive Weighting (SAW)," Jurasik (Jurnal Ris. Sist. Inf. dan Tek. Inform., vol. 2, no. 1, p. 84, 2017.

[11] S. Abubakar, "Pemilihan Objek Wisata Kota Labuan Bajo Menggunakan Metode Simple Additive Weighting ( SAW )," JATI (Jurnal Mhs. Tek. Inform., vol. 2, no. 2, pp. 270-274, 2018. 


\section{Jurnal ELTIKOM : Jurnal Teknik Elektro, Teknologi Informasi dan Komputer}

[12] M. N. El Ghiffary, T. D. Susanto, and A. H. Prabowo, "Analisis Komponen Desain Layout, Warna, dan Kontrol pada Antarmuka Pengguna Aplikasi Mobile Berdasarkan Kemudahan Penggunaan (Studi Kasus: Aplikasi Olride),” J. Tek. ITS, vol. 7, no. 1, 2018.

[13] M. I. A. Handayani, "Perencanaan Perekrutan Kriteria Sumber Daya Manusia PT Varia Usaha Beton (Studi Kasus Pada Proyek Pembangunan Jalan Tol Dan Pusat Perbelanjaan)," J. SPREAD, vol. 7, no. 2008, pp. 159-170, 2017.

[14] K. Muqorobin, A. Apriliyani, "Sistem Pendukung Keputusan Seleksi Penerimaan Beasiswa Dengan Metode SAW," J. Ilm. Teknol. Inf. Terap., vol. 3, no. 01, p. 3, 2019.

[15] R. Taufiq, A. A. Permana, T. Cahyanto, and R. Adha, "Sistem Pendukung Keputusan Penerimaan Karyawan Menggunakan Simple Additive Weighting Studi Kasus PT. Trafoindo Prima Perkasa,” J. Al-Azhar Indonesia., vol. 4, no. 4, pp. 186-194, 2018. 